\title{
Research on Planning Management of the Leisure and Tourism- oriented Suburban Villages Based on System Theory
}

\author{
Li Han, Yong Liu, Jingyuan Zhao, Yuejing Gao \\ College of Architecture, Chang'an University, Xi'an,china,710061
}

\begin{abstract}
Because planning management of the leisure and tourism-oriented suburban villages lags behind, a series of problems occur: sustainable development of rural tourism is limited, and the content of planning management is unclear, and implement does not reach the designed position. In order to solve these problems, through research and analysis, we master the status quo of planning management of leisure and tourism-oriented suburban villages in China, and determine the content of planning management. The author analyze the interactive relationship between system theory and leisure and tourism-oriented suburban rural planning management and construct a planning management system based on the perspective of systems theory. The informatization design of system was achieved by information technology. The results show that the informatization system based on the perspective of system theory not only provides a solution for the planning management of the leisure and tourism-oriented suburban villages, but also lays a foundation for software development and website function design.
\end{abstract}

\section{Introduction}

Leisure and tourism-oriented suburban villages are obviously different from ordinary rural areas for their planning management has their own particularities. At present, domestic and foreign scholars have done a lot of research on rural planning management. Their research results include the theory, regulations, policies, and content of planning management. However, there is a lack of research on the planning management of the leisure and tourism-oriented suburban villages. The current research only regards one or more pieces of content of rural planning management as the research object, without considering the planning management as a whole to carry out systematic research.

Markuszewska, I (2017) described the lack of corresponding legal documents as a support for the Polish rural integrated management tool ${ }^{[1]}$. Chen Yelong (2012) explored an operable management path that is consistent with the village's reality from the aspects of planning management as well as planning and implementation management in view of the problems existing in the village planning management in China ${ }^{[2]}$. Tao Weisheng (2013) demonstrated the origin and development of the urban planning establishment method under the systematic thinking mode, and put forward the idea of the optimization of urban planning establishment method ${ }^{[3]}$. Fencík Róbert et al. (2014) proposed the establishment of a village space model based on the spatial database to provide geographic information support for the government to effectively manage villages ${ }^{[4]}$. Dong Mengyuan (2013) established the integrated business management platform for
Taizhou with the mainline of "planning management business process" and the core of "one book and two certificates" by means of information technology ${ }^{[5]}$. Li Juan et al. (2013) put forward the establishment of community management system based on JQuery technology to achieve effective management for the community ${ }^{[6]}$.

\section{The interactive relationship between system theory and planning management of the leisure and tourism- oriented suburban villages}

\subsection{System theory}

The founder of system theory is an Austrian-American theoretical biologist and philosopher, Ludwig Beraranfi, who believes that the system is composed of several interrelated basic elements and is an organic integrity with certain characteristics and functions. The system consists of three elements, namely the components of the system and their attributes, the environment of the system and its boundaries, and the input and output of the system. It can be shown in the Figure $1^{[7,8] \text {. }}$

*Corresponding author: 181695859@qq.com 


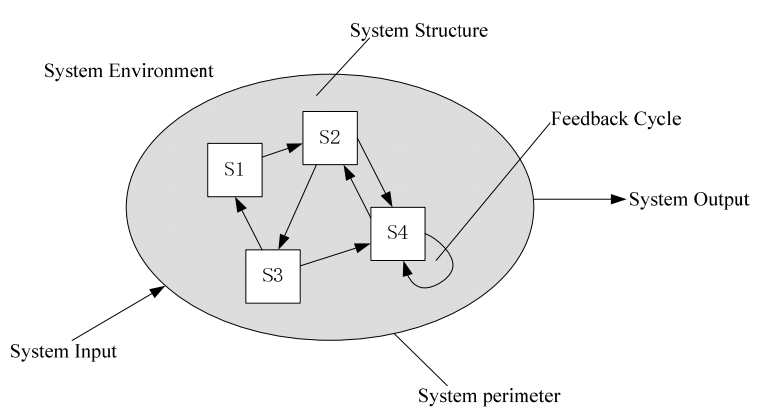

Figure 1. The basic concepts of system(S1,S2,S3,S4-System Units)

\subsection{Planning management of the leisure and tourism-oriented suburban villages}

\subsubsection{The content of planning management of the leisure and tourism-oriented suburban villages}

Leisure and tourism-oriented suburban rural areas are located outside urban built-up areas where the urban environment transforms to rural environment and urban function and rural function are mutually infiltrating. Their development and construction are influenced and radiated by urban to a certain extent. As leisure tourism destinations, they are rich in human resources and natural landscape resources, with tourism as the leading industry and the rural value as the core ${ }^{[9,10,11]}$. The implementation of planning management of the leisure and tourism-oriented suburban villages mainly includes the following three aspects: 1) planning the approval management of establishment; 2) planning and implementation management; and 3) the supervision and inspection management after the approval of planning $[12,13]$.

\subsubsection{Status quo of planning management of the} leisure and tourism-oriented suburban villages

Nine rural tourism destinations in Chengdu and Xi'an are selected to carry out the survey (details are shown in Table 1). Firstly, they tends to be scenic; second, there are numerous types of planning establishment of them; and third, Shaanxi Province requires that rural construction should obtain site selecting position paper and village-and-town construction license, while Sichuan Province only requires the construction institution or individual to obtain position paper of village-and-town location $^{[14,15]}$.

Table 1. The details of the destinations

\begin{tabular}{|c|c|c|}
\hline Name & Status & Planning establishment \\
\hline $\begin{array}{c}\text { Qinglian } \\
\text { International } \\
\text { Poetry Town }\end{array}$ & $\begin{array}{c}\text { National cultural } \\
\text { industrial park }\end{array}$ & $\begin{array}{c}\text { Overall Planning of the } \\
\text { Construction of Qinglian } \\
\text { Poetry Town }\end{array}$ \\
\hline $\begin{array}{c}\text { Sansheng Hua } \\
\text { Town }\end{array}$ & $\begin{array}{c}\text { National 4Aclass tourist } \\
\text { attraction }\end{array}$ & $\begin{array}{c}\text { Tourism Development } \\
\text { Plan for Sansheng Hua }\end{array}$ \\
\hline Lihua Village & $\begin{array}{c}\text { National 4Aclass tourist } \\
\text { attraction }\end{array}$ & \\
\hline $\begin{array}{c}\text { Mingyue } \\
\text { Village }\end{array}$ & - & - \\
\hline Nongke Village & $\begin{array}{c}\text { National 4Aclass tourist } \\
\text { attraction }\end{array}$ & $\begin{array}{c}\text { Nongke Village Tourism } \\
\text { Planning }\end{array}$ \\
\hline \multicolumn{2}{|c}{} \\
\hline
\end{tabular}

\begin{tabular}{|c|c|c|}
\hline Tangzi Village & $\begin{array}{c}\text { National 4Aclass tourist } \\
\text { attraction }\end{array}$ & - \\
\hline $\begin{array}{c}\text { Shangwang } \\
\text { Village }\end{array}$ & - & $\begin{array}{c}\text { Star Leisure Farmhouse's } \\
\text { Overall Planning of } \\
\text { Shangwang Village }\end{array}$ \\
\hline Yuanjia Village & $\begin{array}{c}\text { National 4Aclass tourist } \\
\text { attraction }\end{array}$ & - \\
\hline Maweiyi & $\begin{array}{c}\text { National 4Aclass tourist } \\
\text { attraction }\end{array}$ & $\begin{array}{c}\text { Overall Planning of } \\
\text { Mawei Scenic Area }\end{array}$ \\
\hline
\end{tabular}

2.2.3 Problems of planning management of the leisure and tourism-oriented suburban villages

There are four problems : 1) guidelines for the planning establishment of planning management of the leisure and tourism-oriented suburban villages have not been laid down; 2) there are many modes for planning management of the leisure and tourism-oriented suburban villages, and the planning establishment is not systematic and integrated, resulting in a large number of duplicative establishments; 3 ) in the process of planning and implementing management, the rural construction planning permit system has not been fully implemented; 4) the planning management have been severely disconnected, and some management links are missing.

\subsection{Analysis of interactive relationship}

The interactive relationship between system theory and planning management of the leisure and tourism-oriented suburban villages is shown in the following four aspects: 1) the three aspects of planning management are interdependent and mutually restrictive, which is in line with the integrity and relevance of the system; 2) planning management work is a progressive and forward-type management process, which is highly compatible with the orderliness and purposiveness of the system; 3) the planning management work is affected by many environmental factors, which is in accordance with the environmental adaptability of the system.

\section{System construction of planning management of the leisure and tourism- oriented suburban villages}

\subsection{Related analysis of planning management of the leisure and tourism-oriented suburban villages system}

\subsubsection{Analysis of system environment}




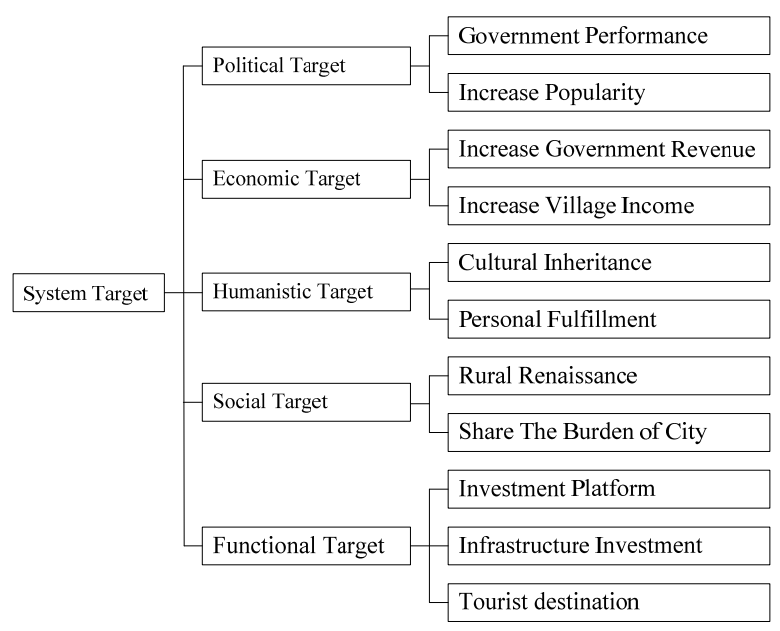

Figure 2. The system target tree of planning management of the leisure and tourism-oriented suburban villages

The system environment includes four aspects: policies and regulations are the bases of the planning management system and play vital roles in the entire management system; social economy is the important safeguard for the management system; the natural ecology can provide natural resources for the project, and different natural ecological environments and resource endowments determine the different development modes of rural tourism. The human resources include the staff, administrative personnel, supervision and inspection personnel, and construction personnel, who play vital roles in the operation of the system.

\subsubsection{Analysis of system input}

The input of the management system includes two parts: the overall input and the specific input. The overall input includes the expectations of the relevant stakeholders. The specific input includes human, material, and financial resources. The overall input includes the expectations of various stakeholders in rural tourism. Financial input refers to the capital investment used in the planning management process. Human input means the human resources investment in management work. Material input indicates all materials that can be mobilized in management work.

\subsubsection{Analysis of system output}

The clear system goal is the premise that ensures the system output is valid. The system target guides the system output. At the same time, the system output also feeds back to the system target. The system target is represented by the target tree shown in Figure 2. The various subsystems of the management system cooperate with each other, and the output of each subsystem ultimately contributes to the final output of the system, that is, a smooth-running rural tourism project satisfies the interests of relevant stakeholders and ensures that the management work can be carried out smoothly.

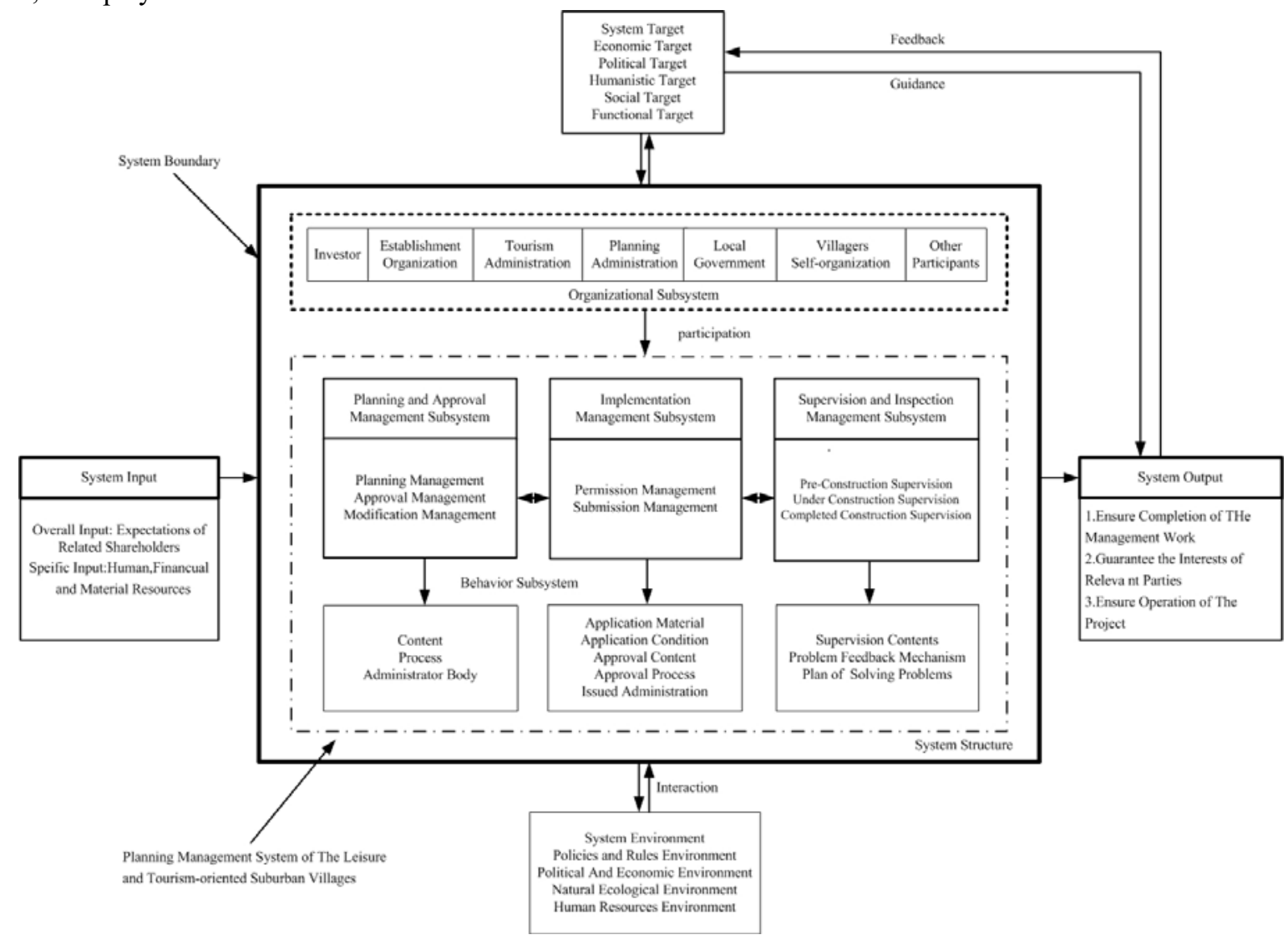

Figure 3. The system framework of planning management of the leisure and tourism-oriented suburban villages 


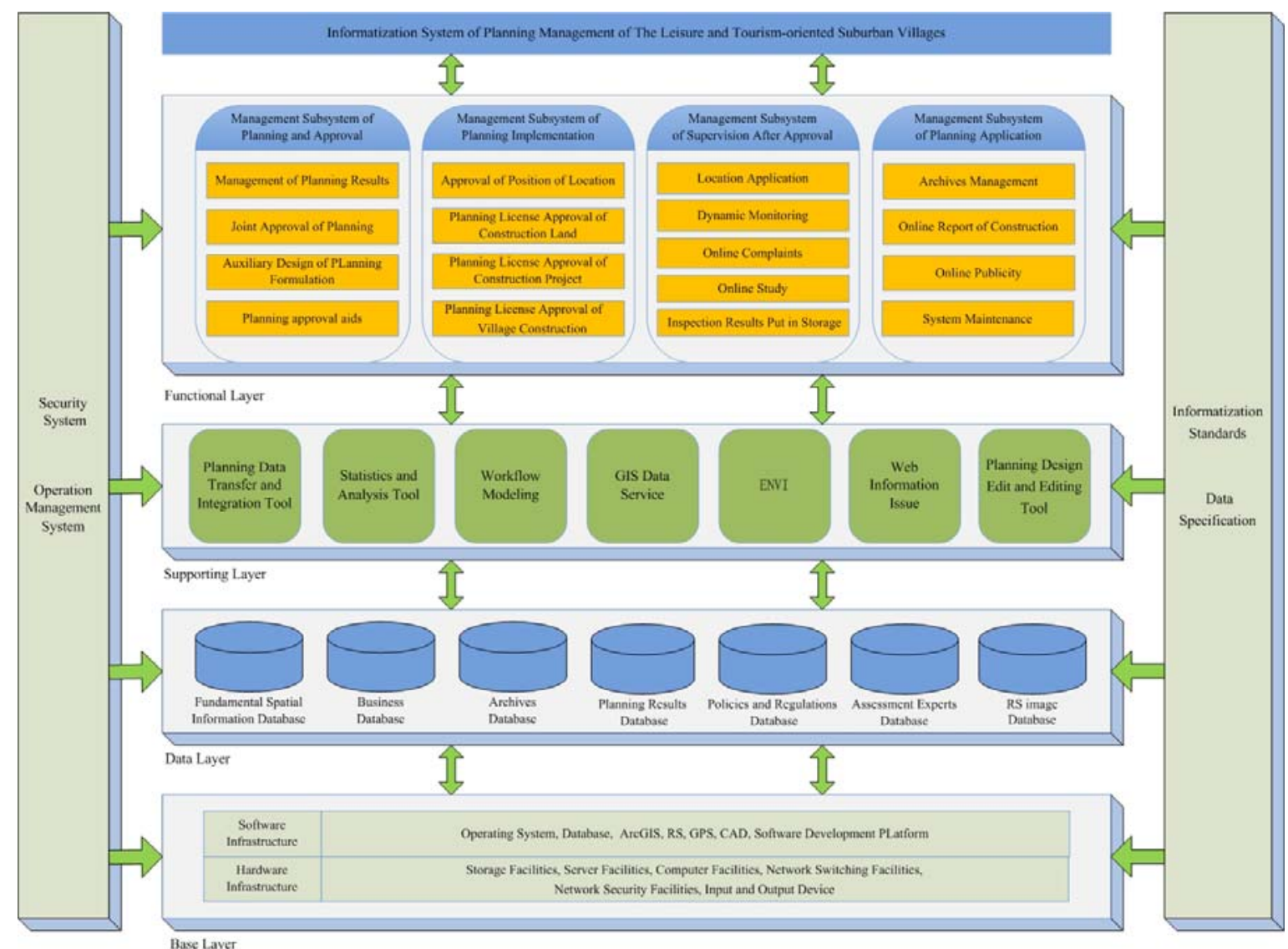

Figure 4. The overall architecture of information system

\subsection{The framework construction of planning management system of the leisure and tourism- oriented suburban villages}

The various participants of the management system form a management collective through administrative constraint relationships and contract relationships. In order to achieve the common project targets, they undertake respective project tasks to constitute the participants of the planning management. The management system framework is shown in Figure 3.

\section{Information design of planning management system of the leisure and tourism-oriented suburban villages}

\subsection{Related analysis of system information design}

\subsubsection{Design concept}

Informatization design of planning management system of the leisure and tourism-oriented suburban villages demands for geographic information system (GIS), database technology, computer-aided design and other information technologies. It concludes planning graphics, texts, and forms management and it runs through the whole planning management business to achieve office information, process standardization, graphic transfer electronization, approval management scientization of the planning management business.

\subsubsection{Design goals}

The first is to provide input, storage, and query of data for planning management system of the leisure and tourism-oriented suburban villages; the second is the application, verification, and certification of the "one book, three certificates" business; the third is the supervision and inspection after the approval of planning, the dynamic supervision of projects after approval, and to discover and investigate illegal behaviors in time; forth is information integration and decision aids, and to carry out comprehensive evaluation and judgment on the basis of multi-source data integration to improve the scientificity and comprehensiveness of planning results.

\subsubsection{Design demands}

The demands of the informatization design of planning management system of the leisure and tourism-oriented suburban villages include overall demands and specific demands. The overall demands include sharability, convenience, reliability, security, standards, and scalability. The functional demands include planning results management, auxiliary design of planning and formulation, planning joint approval, planning assisting 
approval, "one book, three certificates" approval, supervision and inspection after approval, and application management functions.

\subsection{Overall design of system informatization}

The overall design of planning management system of the leisure and tourism-oriented suburban villages is supported by the management tool platform, with database design as the core. Through the hardware and software facilities of the basic layer, the overall design achieves system functions, supporting informatization standards, data standards, and security systems and satisfies different needs of customers. According to the system targets and system requirements, the overall framework of the system consists of five levels, and each level is independent of each other and together ensures the stable operation of the system, which is shown in Figure 4.

\subsection{Functional design of system informatization}

Functional design of system informatization includes four aspects: management subsystem of planning and approval, management subsystem of planning and implementation, management subsystem of supervision and inspection after approval, and management subsystem of planning and application. The management subsystem of planning and application is used as an example to illustrate the design ideas. The functions of the management subsystem of planning and application include four aspects: online report of construction, online publicity, archives management, and system maintenance. Online report of construction refers to the fact that all planning approval items achieve online report through the function of this module. As for online publicity, the system sets publicity column to publicize the project's approval status, approval results, violation information, and planning results, as well as receiving feedback. It is shown in Figure 5.

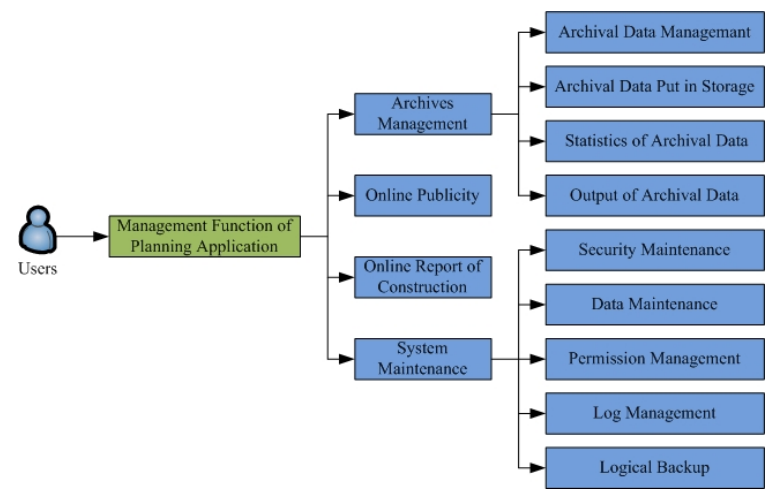

Figure 5. The design of management function of planning application

\section{Conclusion}

The research conclusions of this paper include the following three aspects: firstly, the paper sorts out the planning management of the leisure and tourism-oriented suburban villages and concludes the content of the planning management of it; secondly, it analyzes the interactive relation between planning management of the leisure and tourism-oriented suburban villages and system theory and establishes a management system framework based on the perspective of system theory; thirdly, after the construction of planning management of the leisure and tourism-oriented suburban villages, it carries out informatization design for the system with information technology.

As the planning and construction management of the leisure and tourism-oriented suburban villages is greatly affected by regional and human factors, the management of different regions is very different. At the same time, further development of village tourism has exacerbated the urgency of solving planning management issues. Different development models also increase the complexity of management. Therefore, there are still many deficiencies in this study. Some of links of the planning management system of the leisure and tourismoriented suburban villages are not well considered and do not take into account the differences in management content caused by regional differences. The informational design of planning management system of the leisure and tourism-oriented suburban villages is very professional and requires a variety of computer technologies. Due to the lack of corresponding professional backgrounds, it is difficult to avoid omissions in the informatization design of system, which bring troubles to follow-up platform development and website functions design.

\section{Acknowledgements}

This work is supported by "Twelfth Five-Year" National Science-and-Technology-Support Plan Project(2015BA L01B02), the National Natural Science Foundation of Ch i-na(51678058), the Central Universities' Basic Research Project(310841172101), and the Shanxi Provincial Soci alScience Association (213041160045).

\section{References}

1. Markuszewska I. Conflicts between legal policy an drural area management in Poland[J]. Acta Geograp h- ica Slovenica-Geografska Zbornik,2017,V58 (1): 59-67

2. Chen Yelong. Exploration of Village Planning and Management for Operationality-Taking the Constr -uction of Beautiful Villages in Tongling City as an Example [J]. Planner, 2012,(10):22-25

3. Tao Weisheng. Research on Optimization of Urban Planning Methodology Based on Systematic Thinking Mode [D]. Anhui Jianzhu University, 2013

4. Fencík Róbert,Franc Martin,Itvánffy Ivan,et al.Spati -al model of the village to support the management of public administration[A].Proceeding of Internatio nal Multidisciplinary Scientific GeoConference Surv eyi-ng Geology and Mining Ecology Management 
[C], International Multidisciplinary Scientific Geo confer-ence,2014:801-808

5. Dong Mengyuan. Design and Implementation of Pla -nning Management Information Platform of Taizho u City Construction [D]. University of Electronic Sc ie-nce and Technology of China, 2013

6. Li Juan,Li Huiyin. Management system of SanBao v illage peace district based on JQuery[A]. Proceeding of 2013 5th International Conference on Computati onal and Information Sciences[C], IEEE Computer Society, 2013:336-339

7. Gu Peiliang. System Analysis and Coordination [M]. 2.Tianjin:Tianjin University Press,2008.23-26

8. Wang Yan. Research on Obstacles of Cooperative I nnovation in Industry, University and Research Insti t-ute in China from the Perspective of System Theor y [D].Tianjin University, 2010

9. Jia Jun. Study on the Development of Suburban Vill -age Tourism[D]. Southwest University,2008

10. Zhu Enqi. Research on Suzhou Tourism-oriented Vi -llage Planning [D]. Suzhou University of Science a nd Technology,2009

11. Huang Huajing, Yan Fengtian, Yang Shen. Explorin -g the Planning of Constructing Tourism-oriented Vi 1-lages-Taking Two Villages in Beijing as Exampl es [J]. Small Town Construction,2006,(07):86-90

12. Tenth National People's Congress Standing Commit -tee. The Urban and Rural Planning Law of the Peop l-e's Republic of China [J]. The State Council Bullet in of the People's Republic of China. 2007-12-10

13. Central Committee of the Communist Party of Chin a.The Regulations of Village and Town Planning an d Construction [Z].1993-06-29

14. The Tenth People's Congress Standing Committee i $n$ Sichuan Province. The Regulations of Village Plan $\mathrm{n}$-ing and Construction in Sichuan Province [Z].200 4-09-24

15. The Elventh People's Congress Standing Committee in Shaanxi Province. The Regulations of Village Pl a-nning and Construction in Shaanxi Province [Z].2 010-05-27 